\title{
Ultrastructure and cytochemistry of extramural substances associated with intercellular hyphae of several rust fungi
}

\author{
D. E. Harder, J. Chong, and R. Rohringer \\ Agriculture Canada Research Station, 195 Dafoe Road, Winnipeg, Man., Canada R3T 2M9 \\ AND \\ K. Mendgen, A. Schneider, K. Welter, and G. Knauf \\ Universität Konstanz, Fakultat Biologie, Lehrstuhl Phytopathologie, D7750 Konstanz, Federal Republic of Germany
}

Received August 12, 1988

Harder, D. E., Chong, J., Rohringer, R., Mendgen, K., Schneider, A., Welter, K., and Knauf, G. 1989. Ultrastructure and cytochemistry of extramural substances associated with intercellular hyphae of several rust fungi. Can. J. Bot. 67: $2043-2051$.

Several types of extramural substance(s) associated with rust fungal intercellular hyphae were identified using a variety of tissue processing techniques. With conventional glutaraldehyde- $\mathrm{OSO}_{4}$ fixing and uranyl acetate - lead citrate staining, little material could be discerned on the hyphal surfaces in nonsporulating areas except at locations of cell - cell contact, where a lightly staining fibrous or darker staining amorphous material was apparent. Freeze-substitution or freeze-fracturing preserved greater amounts of coating material, which could be distinguished from the outer fungal wall layers. In freezesubstituted samples the extramural material was amorphous in nonsporulating areas, whereas near sporulating zones it had a fibrous consistency, with the fibrils oriented perpendicularly to the fungal wall. At locations of cell -cell contact there was additional extramural material that was composed of randomly oriented fibrils or was amorphous and densely staining. All types of extramural material stained positively with the periodate - thiocarbahydrazide - silver proteinate or periodate chromate-phosphotungstate stains, but Concanavalin A bound only to some of the dense amorphous material. Sodium ethoxide etching and platinum-carbon shadowing also revealed the extramural material. When rust-infected wheat leaves were flooded with suspensions of colloidal gold, adhesion of gold particles. occurred outside the hyphal walls and coincided with the location of extramural material.

Harder, D. E., Chong, J., Rohringer, R., Mendgen, K., Schneider, A., Welter, K., et Knauf, G. 1989. Ultrastructure and cytochemistry of extramural substances associated with intercellular hyphae of several rust fungi. Can. J. Bot. 67 : $2043-2051$.

En traitant les tissus de diverses façons, les auteurs ont pu identifier plusieurs types de substance(s) pariétales associées avec les hyphes intra-cellulaires de rouille. En traitant avec la méthode conventionnelle soit la fixation au glutéraldéhyde $-\mathrm{OsO}_{4}$ et la coloration à l'acétate d'uranyle - citrate de plomb, très peu de matêriel peut être mis en évidence sur la surface des hyphes dans les régions non-sporulantes, excepté aux endroits de contacts intercellulaires où on observe un matériel fibreux légèrement coloré ou un matériel amorphe plus fortement coloré: La substitution en congélation ou le cryodécapage conservent de plus grandes quantités de matériel de recouvrement qu'on peut distinguer des couches pariétales externes du champignon. Dans les échantillons substitués en congélation, le matériel extra-pariétal des régions nonsporulantes est amorphe, alors que dans les régions en sporulation il montre une consistance fibreuse, avec des fibrilles orientés perpendiculairement par rapport à la paroi fongique. Aux sites de contacts inter-cellulaires, il y a du matériel extrapariétal additionnel composé de fibres orientées au hazard, ou amorphe et densément coloré. Tous les types de matériel extra-pariétal prennent la coloration avec le périodate - chromo-phosphotungstate d'argent protéiné ou le périodatechromo-phosphotungstate, mais la Concanavaline A ne s'attache qu'à du matériel amorphe dense. Le traitement à l'éthoxyde de sodium et l'ombrage au platine-carbone révèlent également le matériel extra-pariétal. Lorsqu'on immerge des feuilles de blé infectées par la rouille dans une suspension d'or colloïdal, l'adhésion des particules d'or se fait à l'extérieur des parois de l'hyphe et coïncide avec la localisation du matériel extra-pariétal.

Konstanzer Online-Publikations-System (KOPS)

URL: http://www.ub.uni-konstanz.de/kops/volltexte/2008/4838/

URN: http://nbn-resolving.de/urn:nbn:de:bsz:352-opus-48382

\section{Introduction}

An understanding of the nature of the surface of rust fungal intercellular hyphae is important because surface interactions may have protective, adhesive, or specificity functions and may be related to the establishment of compatibility or incompatibility. Intercellular washing fluids contain glycoproteins that are related to specificity (Rohringer and Martens 1987). One possible in vivo location of these glycoproteins is the fungal cell surface. However, the structural or chemical nature of these hyphal surfaces is not yet well understood. An outer layer of the intercellular hyphal wall, as detected by conventional processing methods for electron microscopy, has been interpreted as a mucilaginous, possibly adhesive coating substance (Harder 1984; Littlefield and Heath 1979), but more recently Chong et al. (1985) supplied evidence that this layer in fact is a structural component of the fungal wall. However, Beckett and Woods (1987) indicated that a similarly identified layer probably was not structural.

Conventional processing for electron microscopy has been inadequate to demonstrate materials that may coat the surface of rust fungal intercellular hyphal cells. The frequent aqueous and organic solvent washes involved in conventional processing may remove much of the extramural substance(s). Work on several yeasts has shown preservation of cell surface structures by cryoprocessing that had not been possible with conventional procedures (Baba and Osurni 1987; Käppeli et al. 1984; Walther et al. 1984; Tokunaga et al. 1986).

This study was undertaken to further elucidate the occurrence and possible nature of coating substances on the intercellular hyphae of several rust fungi, using various processing and cytochemical techniques. 


\section{Materials and methods}

\section{Plant materials and inoculation}

Seedlings of Triticum aestivum L. and Hordeum vulgare L. emend. Lam. were inoculated with a compatible race (C-17) of Puccinia graminis Pers. f.sp. tritici Eriks. \& Henn. as detailed previously (Chong and Harder 1980). Similarly, leaves of Avena sativa L. cv. Selma were inoculated with the compatible race HKR 2 of $P$. coronata Cda. f.sp. avenae Eriks., and leaves of Phaesolus vulgaris L. with the compatible race SWBR of Uromyces appendiculatus (Pers. ex Pers.) Ung. var. appendiculatus.

\section{Conventional fixing and staining for electron microscopy}

Developing pustules were sampled 5 days after inoculation. The excised tissue was fixed with glutaraldehyde, then either postfixed with osmium tetroxide $\left(\mathrm{OsO}_{4}\right)$ or processed further without $\mathrm{OsO}_{4}$ fixation (Chong and Harder 1980). Ultrathin sections were mounted on Formvar and carbon-coated $149-\mu \mathrm{m}$ (100-mesh) copper grids and stained with uranyl acetate (UA) and lead citrate $(\mathrm{PbC})$.

\section{Histochemical detection of polysaccharides}

The periodate-chromate - phosphotungstate (PACP) (Roland et al. 1972) and periodate - thiocarbohydrazide - silver proteinate (PA TCH-SP) Thiéry (1967) staining methods were used, with appropriate controls (Chong and Harder 1980).

\section{Freeze fracture}

Specimens were vacuum infiltrated with tap water, mounted, and frozen with no prior treament in a Balzers HPM 010 high-pressure freezing device. After freezing the samples were fractured, etched, and shadowed as described by Harder and Mendgen (1982) and Knauf and Mendgen (1988).

\section{Freeze substitution}

Three preparatory regimes for freeze substitution were used: (i) Specimens were infiltrated either with tap or distilled water containing $8 \%$ methanol and high-pressure frozen as above. This was followed by freeze substitution with concomitant fixing in acetone containing $4 \% \mathrm{OsO}_{4}$, at $-80^{\circ} \mathrm{C}$. (ii) A pair of pliers with gold-plated jaws were precooled in liquid nitrogen $\left(\mathrm{LN}_{2}\right)$, and after rapidly withdrawing from the $\mathrm{LN}_{2}$, a portion of an infected leaf was clamped between the plier jaws, then quickly reimmersed in $\mathrm{LN}_{2}$. The frozen tissue pieces were then transferred to $100 \%$ acetone to which a $70 \%$ solution of glutaraldehyde had been added to a final concentration of $3 \%$, dried with molecular sieves, and precooled to $-80^{\circ} \mathrm{C}$. After 7 days of substitution at $-80^{\circ} \mathrm{C}$, the glutaraldehyde-acetone substitution medium was changed and substitution continued for 4 more days. The samples were then transferred to dry acetone with $2 \% \mathrm{OsO}_{4}$ and further substituted for 4 days. The samples were then gradually warmed to room temperature, rinsed in dry acetone, and embedded in Epon-Araldite. (iii) Infected tissue pieces; ca. $1 \mathrm{~mm}$ in diameter, were punched from the leaves with the end of a hypodermic needle that had been square-cut and sharpened. The pieces were frozen by rapidly plunging them into a well of liquified propane, cooled in a surrounding jacket of liquid nitrogen. Freeze substitution was as in (ii) above.

\section{Concanavalin $A$ (ConA) binding}

Gold granules with an average diameter of $5 \mathrm{~nm}$ were prepared and coated with ConA according to the method of Horisberger and Rosset (1977). Ultrathin sections of glutaraldehyde-fixed samples were floated for $2 \mathrm{~h}$ on solutions containing the gold-bound lectin, washed overnight with the appropriate buffer, deposited on copper grids, and stained with $1 \%$ UA.

\section{Etching-shadowing}

This procedure was based on that of Schneider and Wardrop (1979). Sections mounted on 149- $\mu \mathrm{m}$ (100-mesh) Formvar and carbon-coated nickel grids were treated with a saturated solution of sodium hydroxide in ethanol, washed, dried, and shadowed under vacuum with platinum-carbon at an angle of $15-22^{\circ}$. The length of treatment in sodium ethoxide varied with the embedding plastic used. Treatment of 1-2 min was sufficient to remove Spurr's or EponAraldite resins, but up to $4 \mathrm{~min}$ were required to dissolve Epon.

\section{Protease treatment}

Infected tissue fixed with glut was treated with protease (Sigma, type V, purified, $1-5 \mathrm{mg} \cdot \mathrm{mL}^{-1}$ in $0.05 \mathrm{M}$ Tris $-\mathrm{HCl}$ buffer, $\mathrm{pH}$ 7.5) (Chong and Harder 1980) then dehydrated and embedded.

\section{Colloidal gold injection}

A colloidal suspension of $5 \mathrm{~nm}$ gold particles, prepared by reduction of chloroauric acid with white phosphorous (Horisberger and Rossett 1977), was injected into rust-infected wheat leaves using injectors described by Hagborg (1970). Injection was continued until the flooded intercellular space extended approximately $2.5 \mathrm{~cm}$ from

ABBREviations: ConA, concanavalin A; CPF, tissue frozen with cryopliers; EMS, extramural substance(s); FE, freeze-etch; FS, freeze substitution; FW, fungal wall; GLUT, glutaraldehyde; HCW, host cell wall; HM 1, outermost layer of intercellular hyphal wall; HM 2, second outer layer of intercellular hyphal wall; $\mathrm{HPF}$, high-pressure frozen, $\mathrm{ICH}$, intercellular hyphal cell; Non-SP, nonsporogenous zone; OsO ${ }_{4}$, osmium tetroxide; PACP, periodate-chromate - phosphotungstate; PA - TCH - SP, periodate - thiocarbohydrazide - silver proteinate; PbC, lead citrate; SEE, sodium ethoxide etched; PTA, phosphotungstate; SP, sporogenous zone; SPC, sporogenous cell; UA, uranyl acetate. The processing procedures are cited at the end of each figure legend. All figures illustrate Puccinia graminis f.sp. tritici unless otherwise indicated.

FIG. 1. Contact zone of an intercellular hyphal cell with a host cell wall. Extramural substance occurs within the angle of contact between the cells and a thin layer of this material (arrow) occurs external to layer $\mathrm{HM} 1$ of the fungal wall. Conventionally processed (Glut-OsO ${ }_{4}$; $\mathrm{UA}-\mathrm{PbC}$ ). Non-SP. $\times 46700$. FiG, 2. Near juncture of intercellular hyphal cell with host cell. A pad (arrow) of amorphopus material occurs between the fungal and host cell walls. Conventionally processed (Glut-OsO ; UA-PbC). Non-SP. $\times 39780$. Fig. 3 . A thin amorphous layer of extramural material (arrow) coating the fungal wall in a nonsporogenous region of the colony. $\mathrm{CPF}-\mathrm{FS}-\mathrm{OsO} 4$; US $-\mathrm{PbC} \times 95280$. Figs. 4, 5, 6. Freeze-substituted intercellular hyphal cells respectively of Puccinia coronata f.sp. avenae, Uromyces appendiculatus, and $P$. graminis f.sp. tritici, occurring near sporogenous tissue. A layer of material with perpendicularly oriented fibrils occurs outside the fungal walls in all three figures. Fig. 4. HPF-FS; UA-PbC. $\times 25000$. Fig. 5. HPF-FS; UA-PbC. $\times 40000$. Fig. 6. CPF-FS - OsO ; UA - PbC. $\times 76530$. Fig. 7. A zone of contact between several intercellular hyphal cells showing an accumulation of extramural material between the cells. This material is composed of a layer of perpendicularly oriented fibrils next to the fungal walls (closed arrows) and a midzone of randomly oriented fibrils (open arrows). SP. CPF-FS-OsO ; US - PbC. $\times 30390$. Fig. 8. A zone of contact between an intercellular hyphal cell and a host cell showing extramural material occurring outside layer HM 1 of the fungal wall. The fungal wall appears very broad because the fungal cytoplasm has shrunk from the wall and PACP does not stain the inner layers of rust fungal walls. CPF - FS-GLUT-OsO PACP. $\times 47660$. Frg. 9. Dark amorphous (arrow) and fibrillar $\left(^{*}\right)$ material occuring between two adjacent intercellular hyphal cells and a host cell. CPF-FS-GLUT-OsO ${ }_{4}$; PACP. $\times 31500$. FIG. 10. Extramural material at the juncture of two intercellular hyphal cells and a host cell (not shown). The material is clearly differentiated from layer HM 1 of the hyphal cell and continues as a thin layer over HM 1 (arrow) away from the juncture region. CPF - FS - GLUT $-\mathrm{OsO}_{4} ; \mathrm{PA}-\mathrm{TCH}-\mathrm{SP}$. $\times 39$ 100. FiG. 11. Three different conformations of extramural substance at a hyphal - host cell juncture. Darkly staining amorphous material occurs immediately between the hyphal cells and a hyphal-host cell juncture, a layer with perpendicularly oriented fibrils (arrow) is adjacent to all cell surfaces, and material with randomly oriented fibrils $\left({ }^{*}\right)$ that fills the space between the cells. CPF-FS-GLUT-OsO 4 ; PA-TCH-SP. $\times 23800$. 

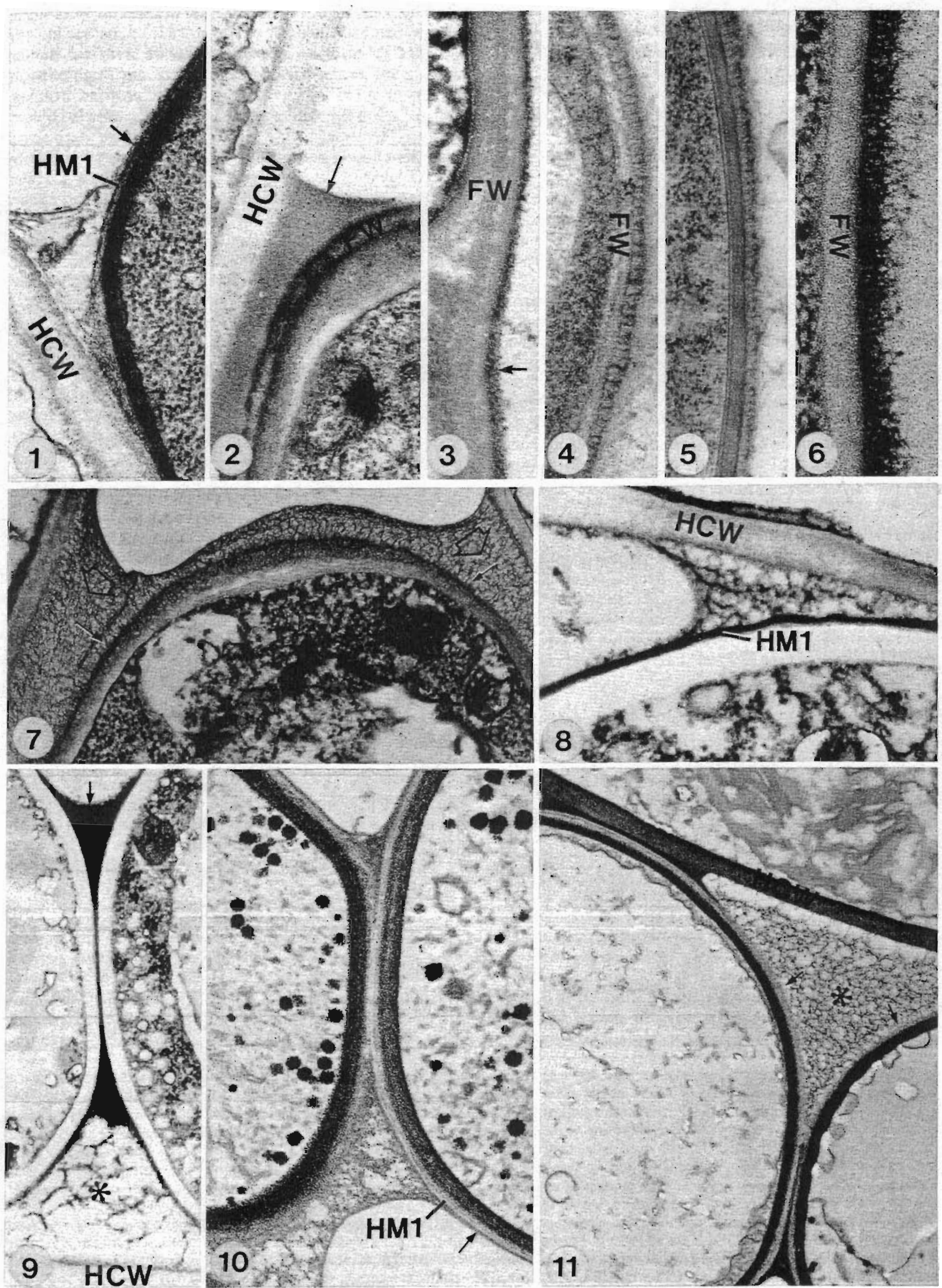
the point of injection. Tissue samples were taken at various distances beginning from a point approximately $1 \mathrm{~mm}$ outside the boundary of the injection apparatus. Preliminary experiments had shown that gold particles were rarely encountered in the intercellular spaces at distances outside the $1 \mathrm{~mm}$ zone; thus all further work was with samples taken from this $1 \mathrm{~mm}$ zone, approximately $18 \mathrm{~mm}$ behind the front of flooding.

\section{Results}

In this study it was important to be able to differentiate any extramural substance(s) from the outermost intercellular hyphal wall layer. We continued the designation of the outer wall layer as $\mathrm{H} / \mathrm{M} 1$, as recognized by previous cytochemical procedures, e.g., PACP staining (Chong et al. 1985).

A further important differentiation that became apparent was the association of extramural substances with location of intercellular hyphae within a colony. Hyphae located within or near sporogenous zones, or where hyphae had aggregated in preparation for sporulation, were differentiated from those that were located well away from sporogenous areas. Where possible, sporogenous cells were identified, based on the description of Harder (1976). Observations within sporulating zones are designated as SP and those not involving sporulating areas as non-SP. The results are presented in terms of the processing and staining methods used.

\section{Conventional processing}

With conventional processing of non-SP hyphae, little material could normally be differentiated outside of layer H/M 1 . At points of contact between adjacent hyphal cells or fungal-host cells, stained material occurred within the angle of contact between the cells (Fig. 1) or as pads of material at points of cell-cell contact (Fig. 2). In Fig. 1 a thin layer of extramural material was evident outside of $\mathrm{H} / \mathrm{M} 1$ near the area of wall-wall contact, but it appeared to merge with $H / M$ 1 away from the contact region. Similarly, in SP tissue, there was little extramural material present except in the areas of cell contact, where there was considerably more substance (see Fig. 11). The consistency and staining properties of the extramural substance(s) ranged from variably fibrillar to amor phous and more densely staining (compare Figs. 1 and 2).

\section{Freeze substitution (FS)}

\section{$U A-P b C$ staining}

In all FS material, whether frozen under high pressure or by the cryopliers method, more extramural material was observable around intercellular hyphae than when conventionally processed, in all of the host - pathogen combinations tested. In non-SP tissue an amorphous layer of variable width, occurring outside of $\mathrm{H} / \mathrm{M} 1$, was frequently detected (Fig. 3). In SP tissue, the extramural substances occurred in several different conformations. Figure 4 shows a band of material, with fibrils oriented perpendicular to the hyphal wall, on the outside of a hypha of $P$. coronata after high-pressure freezing. Similar results were obtained with $U$. appendiculatus (high-pressure freezing, Fig. 5) and with $P$. graminis (propane freezing, Fig. 6). In non-SP regions where hyphal cells were in contact, or where there was contact with host cells, there were larger quantities of extramural material. In SP tissues processed by FS, the layer of material with the perpendicularly oriented fibrils was differentiated from other material that had a more randomly oriented fibrillar composition (Figs. 7, 13; also see PA-TCH - SP stained material, Fig. 11). A third differentiable form of material was amorphous and more densely staining (see Figs. 13,14a,14b), but it occurred infrequently.

\section{$P A C P$ and $P A-T C H-S P$ staining}

Previously it was shown (Chong et al. 1985) that layer $H / M 1$ and to some extent layer H/M 2 stained intensely with PACP, using conventional processing techniques. This procedure was repeated using FS samples. Layers H/M 1 and 2 stained intensely while the remainder of the wall remained unstained (Fig. 8). PACP also stained the extramural substances at points of cell-cell contact (Figs. 8, 9). As in $\mathrm{UA}-\mathrm{PbC}$ staining, the extramural substances were either fibrillar-like (Fig. 8) or amorphous and more densely staining (Fig. 9). In Fig. 8, the extramural substance appears to lie outside layer $\mathrm{H} / \mathrm{M} 1$. Where the densely staining material occurred, it could not be differentiated from $\mathrm{H} / \mathrm{M} 1$ (Fig. 12).

With PA-TCH-SP staining of conventionally processed material, it has previously been shown (Chong et al. 1985) that $H / M 1$ is only very lightly stained. After FS, layer $H / M$ 1 was also very lightly stained and could be differentiated from extramural substances (Figs. 10, 11). In Fig. 10 (non-SP), the extramural substance appeared as a thin layer outside $\mathrm{H} / \mathrm{M} 1$, expanding to larger amounts of substance at points of cell - cell contact. In Fig. 11 (near-SP), three different configurations of the extramural substances were evident: the space between adjoining cells was largely filled with randomly oriented fibrillarlike material, while adjacent to the fungal walls the fibrils were oriented perpendicularly to the walls, and at points of contact there was amorphous, more densely staining material. All three configurations could occur together as in Fig. 11, but they also occurred individually (not illustrated).

\section{ConA binding}

It was previously shown (Chong et al. 1985) with conventional processing that ConA bound more to the outer portions of the intercellular hyphal walls, including layers $\mathrm{H} / \mathrm{M} 1$ and 2 , than to inner portions of the walls. After FS, ConA similarly bound to outer regions of the hyphal walls corresponding

F1G. 12. A thin layer of extramural material occuring between an intercellular hyphal and host cell. The extramural material (artow) is differentiated from layer HM 1 of the hyphal wall by the lack of affinity of this material to ConA. CPF $-F S-G L U T-O s O_{4}$; ConA $-U A$. $\times 41000$. F1G. 13. Electron-dense amorphous $\left(^{*}\right)$ and fibrillar (arrow) extramural substances occurring at the juncture of several hyphal cells. The fibrillar material lacks ConA affinity, but there is ConA binding to the dense amorphous material. CPF - FS - GLUT-OsO ; ConA-UA. $\times 53600$. FIG. 14. At the juncture of two intercellular hyphal cells, some densely staining, amorphous material bound ConA (Fig. 14a) but other similar material did not (Fig. 14b). CPF-FS-GLUT-OsO 4 ; ConA-UA. $\times 60000$. Fig. 15. Freeze-etch replica of intercellular hyphae, close to SP tissue, of Uromyces appendiculatus with strands of extramural material (arrow) occurring between two cells. HPF - FE. $\times 40000$. FIG. 16. Adjacent sections of the juncture region of several intercellular hyphae, one of which $(a)$ has been etched with sodium ethoxide and the other $(b)$ has been processed conventionally. The etching process has not altered the extramural material (arrows) evident in Fig. 16b. Both sections fixed with GLUT-OsO 4 . (a) SEE-platinum-carbon shadowed. $\times 27800$. (b) UA-PbC. $\times 27800$. FIG. 17. Adjacent sections treated similarly to Fig. 16 . The etching process appears to have removed some extramural material $(*)(a)$, but the more densely stained strands of material (arrows) (b) were left intact. CPF-GLUT-OsO.$(a)$ SEE-platinum-carbon shadowed. $\times 27800$. (b) UA-PbC. $\times 27800$. 


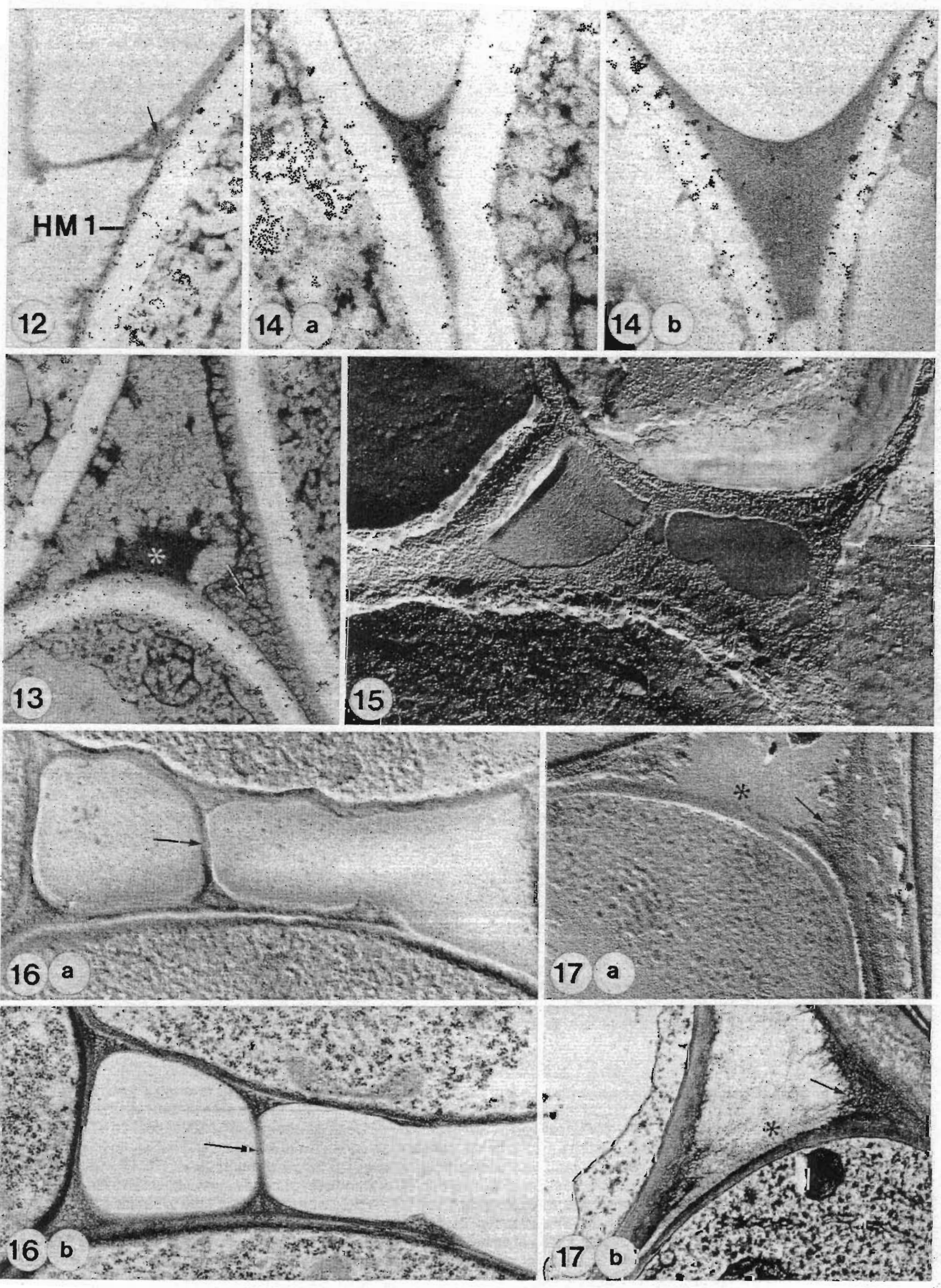


to layers $\mathrm{H} / \mathrm{M} 1$ and 2, but the lectin also had a strong affinity to the inner wall domain (Figs. 12, 14a; non-SP). ConA did not bind to the fibrillar extramural substances in SP tissue (Fig. 13). However, ConA did bind to accumulations of densely staining material that sometimes occurred in the intercellular spaces (Fig. 13). The amorphous, densely staining material that occurred in areas of cell-cell contact inconsistently bound ConA. Figures $14 a$ and $14 b$ show contact between two hyphal cells where little ConA binding occurred in one case (Fig. 14b) but much more in the other (Fig. 14a). The variable binding of ConA to the amorphous material was random and could not be attributed to any particular characteristic or location of the material.

\section{Freeze fracture}

A layer of extramural substance could usually be observed around intercellular hyphae in cross fractures and this material was often continuous between adjacent cells (Fig. 15).

\section{Etching-shadowing}

This technique, by removing the embedding plastic, may reveal structures normally not readily stainable by electrondense stains. Figure 16 shows etched - shadowed $(a)$ and nonetched-stained $(b)$ material in adjacent sections from a conventionally processed sample. The locations and amounts of extramural material appeared similar in both preparations. In other samples extramural substances behaved differentially after etching. In Fig. $17 b$ (FS, UA-PbC stain), the space between two host cells and a fungal cell is filled with fibrillar material, there is a layer with perpendicularly oriented fibrils over the fungal wall, and darker staining material apparently attached to the host walls. In an adjacent section after etching - shadowing (Fig. 17a), only the darker staining materials attached to the host walls remained. In a modification of the method, sections were etched, then stained with phosphotungstate (Fig. 18). This method showed clearly that layers $\mathrm{H} / \mathrm{M} 1$ and 2 were not modified by the etching process. After protease treatment, all signs of extramural substances were removed (Fig. 19), along with layers $\mathrm{H} / \mathrm{M} 1$ and 2 (also see Chong et al. 1985).

\section{Gold colloid injection}

After injection with colloidal gold, a band of gold particles occurred outside the periphery of intercellular hyphal walls but not host walls (Fig. 20). In Fig. 20 there is some background-stained material to which the gold particles appear to have adhered, but when such background substance was not stained, gold particles were evident at a similar location (Fig. 21). After etching-staining (Fig. 22), the gold particles were located similarly to that shown in Fig. 21, whereas after etching-shadowing (Fig. 23), the location of the gold par- ticles corresponded to a shadowed layer lying outside the fungal wall.

The fate of layer H/M 1 appeared to be related to the proximity to a sporulating region. In non-SP areas layer H/M I was normally well defined, but often lost its identity in intercell contact zones in SP areas (e.g., Fig. 24) and as well lost the affinity for ConA (compare Figs. 12 and 13). It was usually in areas where the extramural material appeared in its amorphous densely staining form or with the perpendicularly oriented fibrils that the identity of layer $\mathrm{H} / \mathrm{M} 1$ became less distinct. Close examination of areas where there was heavy production of extramural material showed that $\mathrm{H} / \mathrm{M} 1$ became indistinct from this material (Fig. 24). Often extramural material (Fig. 24) appeared to intervene between the fungal wall and layer $\mathrm{H} / \mathrm{M} 1$.

\section{Discussion}

The outer surface of rust fungal intercellular hyphae appears to be highly complex and variable. The identity of layer H/M 1, as defined by Chong et al. (1985) and referred to by Beckett and Woods (1987), is still not certain. It is important to either relate this layer to, or differentiate it from, other substances that may occur outside the fungal walls. Where layers H/M 1 and 2 occur, they are of uniform thickness and retain their structural identity, even when pressed against adjacent cells (Chong et al. 1985); in this study their structural integrity was retained after dissolution of the embedding plastic. However, Beckett and Woods (1987) interpreted a similarly identified layer as not being a structural component of the fungal wall because it was seen to become separated from the wall in some places. The present study showed that the occurrence of this layer was indeed variable and was related to the degree of hyphal aggregation, leading to sporulation. Around aggregated hyphae, layers $\mathrm{H} / \mathrm{M} 1$ and 2 were often absent, as observed in stained sections and loss of ConA binding to the outer surface of the walls. It was also observed that layer $\mathrm{H} / \mathrm{M}$ 1 became separated from the hyphal wall and in some areas appeared to have merged with an accumulation of extramural material. Thus layers H/M 1 and 2 appear to behave as part of the fungal wall in hyphae at early stages of colony growth but not in sporogenous zones.

The question then arises as to the role of layers $\mathrm{H} / \mathrm{M} 1$ and 2 and their relationship to other surface substances. The apparent structural firmness of layers H/M 1 and 2 (Chong et al. 1985) indicates that they are not mucilaginous (used in a descriptive sense to denote a soft gel-like substance). The problem of distinguishing layers $\mathrm{H} / \mathrm{M} 1$ and 2 from other possible extramural substances was resolved by injecting gold colloids and by various stains following cryoprocessing. With

FIG. 18. A sodium ethoxide etched section stained with PTA instead of shadowed. This method clearly revealed layers HM 1 and HM 2 and remnants of material external to this layer. GLUT-OsO evidence of extramural material remains. GLUT-OsO 4 ; protease; SEE-platinum-carbon shadowed. $\times 12$ 600. FIGs. 20-23. Gold colloid injected samples. Fig. 20. Colloidal particles adhering to a region on the periphery of an intercellular hyphal cell but not to a host wall. Some gold particles appear to have bound to strand of extramural material occurring between the fungal and host walls. GLUT-OsO $\times 53000$. Fig. 21. Gold particles adhering to a similar region as that in Fig. 20 but no background substance is visible. GLUT-OsO 4 ; no stain. $\times 62900$. Fig. 22. Similar to Fig. 21, but sodium ethoxide etched and UA-PbC stained. There is little apparent stained material to which the gold particles are adhering. $\times 36100$. Fig. 23. Similar to Fig. 21, but platinum-carbon shadowed instead of stained. The distribution of gold particles is similar to that in Figs. 21 and 22, but a band of etched material is now apparent outside the fungal wall. $\times 112800$. FIG. 24 . A section from near a sporogenous zone where the intercellular spaces contain large amounts of extramural substances. Layer HM 1 appears to have become separated from the fungal wall in places and has become indistinct from the extramural material. CPF-GLUT-OsO PA - TCH - SP. $\times 30400$. 

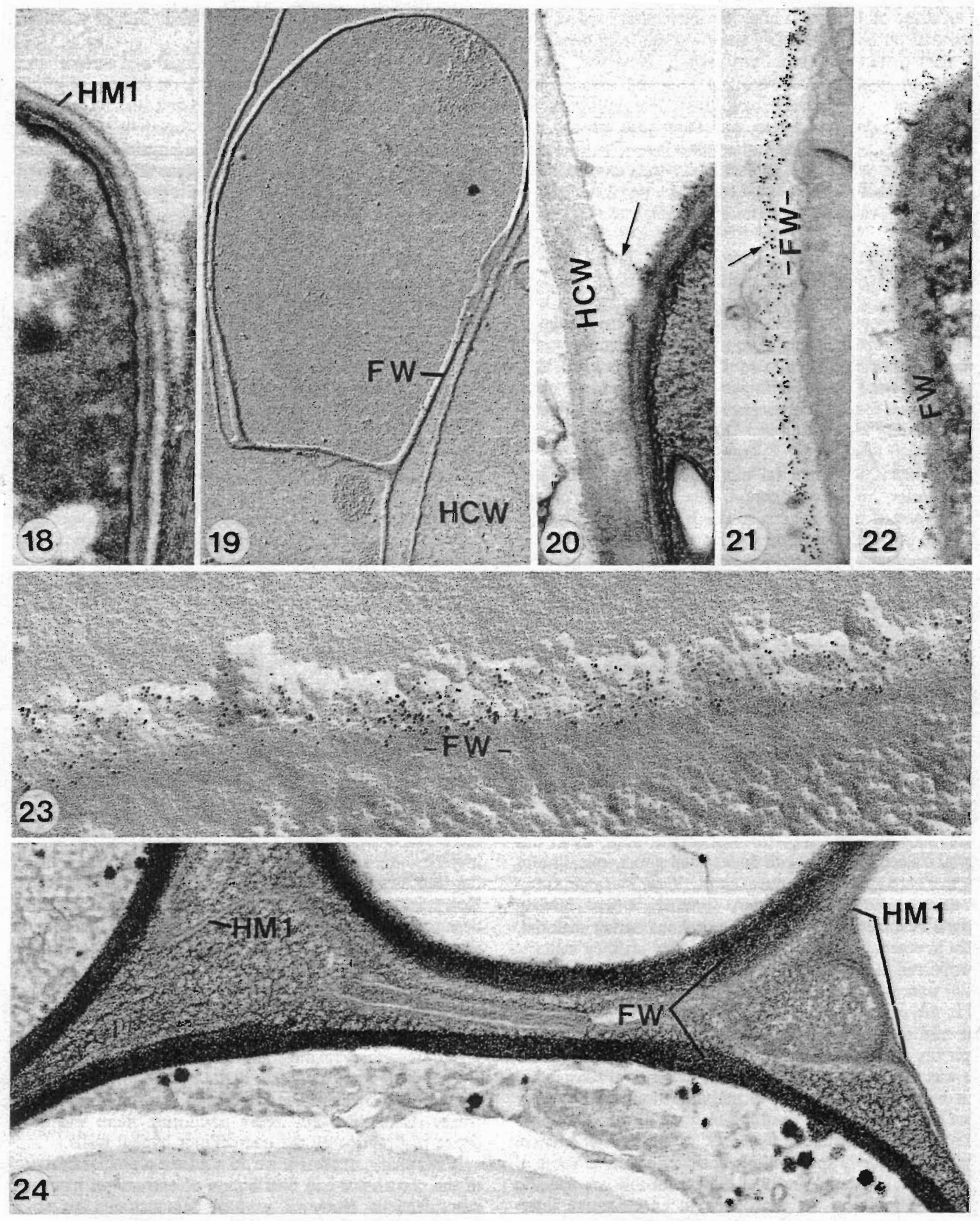
respect to the gold colloid work, it is important to note that none of the colloid that had been injected into the intercellular space became attached to host walls. The gold particles may have localized on host walls after the intercellular spaces had refilled with air but presumably were washed from their surfaces during further tissue processing. However, those deposited on fungal walls were not removed; many were detected there in a relatively thick layer. The gold particles appear to have penetrated into, and then were trapped by, material such as a gel-like or porous substance. The thickness of the layer in which the gold colloids were trapped was greater than that attributable to layers $\mathrm{H} / \mathrm{M} 1$ and 2, indicating that they were localized in an extramural substance that coated the fungal wall.

Freeze substitution followed by PACP or PA-TCH-SP staining also clearly showed material external to $\mathrm{H} / \mathrm{M} 1$. Similar material could not be demonstrated as readily with conventional processing methods. Either the latter methods, involving extensive washing in aqueous and organic solvents, reduced any mucilage to a thin nonresolvable layer on $\mathrm{H} / \mathrm{M} 1$, or much of it was removed during processing. Similarly, cryoprocessing was found to be necessary to preserve surface substances of yeast cells (Baba and Osumi 1987; Käppeli et al. 1984; Walther et al. 1984; Tokunaga et al. 1986).

Several forms of extramural substances were evident, particularly after freeze substitution. The appearance of this material seemed to be related to the location of the hyphae within the rust colony. Hyphae that were well away from sporulating areas usually had a thin amorphous layer of material, whereas in areas of hyphal aggregation leading to sporulation, this substance had a strong fibrous appearance, with variations in the orientation of the fibrillar component. The layer with the perpendicularly oriented fibrils, also observed by Mendgen et al. (1988), was somewhat reminiscent of the hair-like surface layer around cryoprocessed yeast cells (Baba and Osumi 1987; Käppeli et al. 1984; Walther et al. 1984; Tokunaga et al. 1986). The fibrillar type of material predominated, but an amorphous, darker staining substance also occurred, particularly at points of cell to cell contact. It was not clear from these studies how the various forms of extramural substances related to one another, or whether they were of fungal or host origin. Since all of this material stained similarly with the various cytochemical stains used, there are apparent chemical similarities. The main variation encountered was in ConA binding, where binding occurred in some samples of the amorphous darker material, but not in others. ConA also bound to darker staining material that appeared to have become inserted into the fibrous intercellular material. From the results of the variety of methods used in this study, it appears that the extramural environment of the rust intercellular hyphae is highly complex. Most of the complexity occurred in areas of hyphal aggregation where there was more copious production of extramural substances, and it is in areas such as these that secretions from host or fungus could be trapped, resulting in some of the variability. However, the consistent differences in fibrillar orientation indicate that there is specificity in the production of some of the extramural material and that there probably are specific functions. Urediosori are embedded in an extensive intercellular mucilaginous matrix (e.g., Beckett and Woods 1987; Hassan and Littlefield 1979; McCain and Hannen 1984). From the present study it is apparent that there is an extensive accumulation of extramural material (mucilage) during early stages of urediosorus formation and this may well contribute to the matrix of more mature urediosori. How mucilage relates functionally to layers $\mathrm{H} / \mathrm{M} 1$ and 2 and how this complex in turn relates to the remaining layers of the fungal wall remain to be elucidated.

Most of the information on rust fungal cell surface characteristics has been obtained from work on spores, germ tubes, or appressoria. Epstein et al. (1987) and Beckett and Woods (1987) have reviewed some possible functions of wall surface materials, citing a variety of possible physiological functions but mainly implicating cell-substratum adhesion. How this work relates to the intercellular phase of fungal growth remains to be resolved. Cell-cell adhesion has been cited as a factor in thigmotropic surface growth (Epstein et al. 1987) and in addition may play a role in directed intercellular hyphal growth, as suggested by Beckett and Woods (1987).

Polysaccharides, glycoproteins, or proteins have been identified as being involved in cell surface adhesion in a wide variety of fungi (see Epstein et al. 1987; Nicholson 1984 and references therein). Protease has been shown to remove the outermost layers of intercellular hyphal walls (Chong et al. 1985), but in this study we could not differentiate layers H/M 1 and 2 from other surface materials with protease. However, with PA-TCH-SP, the extramural material was differentiated from $\mathrm{H} / \mathrm{M} 1$. Layer $\mathrm{H} / \mathrm{M} 1$ does not react to this stain but the extramural material stained heavily, indicating that it contained an abundance of glycosubstances with vicinal hydroxyl groups. Also, this material does not, except in some instances, appear to contain $\alpha$-linked glucose or mannose, whereas layers $\mathrm{H} / \mathrm{M} 1$ and 2 do, as indicated by their relative ConA affinities (also see Chong et al. 1985). Thus, the major components of extramural substances may be $\beta$-glucans or other polysaccharides with vicinal hydroxyl groups that have little affinity for ConA. This interpretation is consistent with the results of Mendgen et al. (1985), but raises questions regarding the fate of the ConA-binding material in locations corresponding to layers $\mathrm{H} / \mathrm{M} 1$ and 2 when these layers disappear in SP material. The loss of ConA binding to these sites suggests that they may be degraded and dispersed. Surface mucilage on germ tubes and appressoria of $P$. graminis tritici (Harder et al. 1986) similarly had no affinity for ConA, but there was a positive reaction to $\mathrm{PA}-\mathrm{TCH}-\mathrm{SP}$. Thus there may be some similarities between the mucilage generated on the leaf surface and the intercellular extramural substances. However, the spores in the study of Harder et al. (1986) had been conventionally processed and it is possible that some substances, e.g., those that bind ConA, could have been removed.

Proteinaceous "fimbriae" have been reported to occur in a wide variety of fungi, with the antigenicity of the protein(s) conserved across a broad range of genera of fungi (Gardiner and Day 1988). The fimbriae were differentiated from mucilaginous surface coatings and in particular were revealed in freeze-etch replicas (Poon and Day 1975). In the present study, using a wide range of processing techniques, including freeze substitution and freeze fracturing, there was no evidence of fimbriae on the intercellular hyphal walls.

In summary, at present we do not have a precise description of the occurrence and distribution of extramural mucilage in rust infections. However, we have demonstrated the presence of considerable amounts of extramural material, occurring in several different configurations. Components of this material of fungal origin may well be involved in adhesive functions, in conjunction with material of host origin. This and other pos- 
sible functions (e.g., specificity related to compatibility or incompatibility) remain to be elucidated.

\section{Acknowledgements}

We thank Mr. M. Wolf and Mrs. R. Gillespie for expert technical assistance.

BabA, M., and OsUMI, M. 1987. Transmission and scanning electron microscopic examination of intracellular organelles in freeze-substituted Kloeckera and Saccharomyces cerevesiae yeast cells. J. Electron Microsc. Tech. 5: 249-261.

BECKETT, A., and Woods, A. M. 1987. The pattern of colony development and the formation of the uredinium of Uromyces viciae-fabae on Vicia faba. Can. J. Bot. 65: 1998-2006.

ChONG, J., and HARDER, D. E. 1980. Ultrastructure of haustorium development in Puccinia coronata avenae. I. Cytochemistry and electron probe $\mathrm{X}$-ray analysis of the haustorial neck ring. Can. J. Bot. 58: $2496-2505$.

ChONG, J., Harder, D. E., and Rohringer, R. 1985. Cytochemical studies on Puccinia graminis f. sp. tritici in a compatible wheat host. I. Walls of intercellular hyphal cells and haustorium mother cells. Can. J. Bot. 63: 1713-1724.

Epstein, L., Laccetri, B., Staples, R. C., and Носh, H. C. 1987. Cell substratum adhesive protein involved in surface contact responses of the bean rust fungus. Physiol. Mol. Plant Pathol. 30: $373-388$.

GARDINER, R. B., and DAY, A. W. 1988. Surface proteinaceous fibrils (fimbriae) on filamentous fungi. Can. J. Bot. 66: 2474-2484.

HAGBORG, W. A. F. 1970. A device for injecting solutions and suspensions into thin leaves of plants. Can. J. Bot. 48: 1135-1136.

HARDER, D. E. 1976. Electron microscopy of urediospore formation in Puccinia coronata avenae and $P$. graminis avenae. Can. J. Bot. 54: 1010-1019.

1984. Developmental ultrastructure of hyphae and spores. In The cereal rusts. Vol. 1. Edited by W. R. Bushnell and A. P. Roelfs. Academic Press, New York. pp. 333-373.

HARDER, D. E., and MENDGEN, K. 1982. Filipin-sterol complexes in bean rust and oat crown rust-fungal/host interactions: freeze-etch electron microscopy. Protoplasma, 112: 46-54.

Harder, D. E., Chong, J., Rohringer, R., and Kim, W. K. 1986. Structure and cytochemistry of the walls of urediospores, germ tubes, and appressoria of Puccinia graminis tritici. Can. J. Bot. 64: $476-485$.

HASSAN, Z. M., and LitTLEFIELD, L. J. 1979. Ontogeny of the uredium of Melampsora lini. Can. J. Bot. 57: 639-649.

Horisberger, M., and Rosset, J. 1977. Colloidal gold, a useful marker for transmission and scanning electron microscopy. J. Histochem. Cytochem. 25: 295-305.
Käppeli, O., Walther, P., Mueller, M., and Fiechter, A. 1984. Structure of the cell surface of the yeast Candida tropicalis and its relation to hydrocarbon transport. Arch. Microbiol. 138: 279-282.

KnaUf, G., and MENDGen, K. 1988. Secretion systems and membrane-associated structures in rust fungi after high pressure freezing and freeze fracturing. Biol. Cell, 64: 363-370.

Litrlefield, L. J., and HeATH, M. C. 1979. Ultrastructure of rust fungi. Academic Press, New York.

MCCAIN, J. W., and Hennen, J. F. 1984. Development of the uredinial thallus and sorus in the orange coffee rust, Hemileia vastatrix. Phytopathology, 74: 714-721.

MENDGEN, K., LANGE, M., and BreTSCHNeIDER, K. 1985. Quantitative estimation of the surface carbohydrates on the infection structures of rust fungi with enzymes and lectins. Arch. Microbiol. 140: 307-311.

Mendgen, K., Schneider, A., Sterk, M., and FinK, W. 1988. The differentiation of infection structures as a result of recognition events between some biotrophic parasites and their hosts. J. Phytopathol. 123: 259-272.

Nicholson, R. L. 1984. Adhesion of fungi to the plant cuticle. In Infection processes of fungi. Edited by D. W. Roberts and J. R. Aist. Rockefeller Conference Report, Bellagio Conference, March 21-25, 1983. pp. 74-89.

POON, N. H., and DAY, A. W. 1975. Fungal fimbriae. I. Structure, origin, and synthesis. Can. J. Microbiol. 21: 537-546.

ROHRINGER, R., and MARTENS, J. W. 1987. Infection-related proteins in intercellular washing fluids from stem rust-affected wheat leaves: race-associated protein differences revealed by PAGE and ConA blotting. Physiol. Mol. Plant Pathol. 31: 375-386.

Roland, J. C., Lembi, C. A., and Morrè, D. J. 1972. Phosphotungtic acid - chromic acid as a selective electron-dense stain for plasma membranes of plant cells. Stain Technol. 47: 195-200.

SCHNEIDER, E. F., and WARDROP, A. B. 1979. Ultrastructural studies on the cell walls in Fusarium sulphureum. Can. J. Microbiol. 25: $75-85$.

THIÉRY, J. P. 1967. Mise en êvidence des polysaccharides sur coupes fines en microscopie électronique. J. Microsc. (Paris), 6: $987-$ 1018.

TokUnaGa, M., Kusamichi, M., and KoIKu, H. 1986. Ultrastructure of outermost layer of cell wall in Candida albicans observed by rapid-freezing technique. J. Electron Microsc. 35: 237-246.

Walther, P., MÜller, M., and SChWeingruber, M. E. 1984. The ultrastructure of the cell surface and plasma membrane of exponential and stationary phase cells of Schizosaccharomyces pombe, grown in different media. Arch. Microbiol. 137: 128-134. 